\title{
The ‘Double Law’ of Hospitality: Rethinking Cosmopolitan Ethics in Humanitarian Intervention
}

\author{
Gideon Baker
}

\begin{abstract}
By way of a discussion of the deliberately hard case of humanitarian intervention, this article considers the merits of an alternative cosmopolitan ethics to that of liberal cosmopolitanism, one which founds its universalism on an ethics of hospitality rather than the rights of man. Jacques Derrida describes the ethics of hospitality as defined by an unconditional welcome which nonetheless must become conditional in order to function. This leads to a profound paradox - an 'undecidability' - in the practice of the ethics of hospitality, the implications of which need to be better understood if the ambition of 'another cosmopolitanism' is to be realised. Interrogating the ethics of hospitality and the undecidability to which it gives rise in relation to humanitarian intervention, it is argued that responsibilities to others, which sometimes imply intervention, must always be kept in tension with openness to the coming of the Other, which limits intervention. Far from being blind or paralysing action, such 'bounded undecidability', it is suggested, actually defines the site of responsible, just decision in humanitarian intervention.
\end{abstract}

Key words Humanitarian Intervention; Hospitality; Derrida; Cosmopolitanism; Undecidability; Ethics; Humanism; Levinas

This article argues for the importance of Jacques Derrida's work on hospitality for rethinking cosmopolitan ethics and, specifically, for grappling with the ethical minefield surrounding the use of force in humanitarian intervention. ${ }^{1}$ Cosmopolitan ethics in general, and the ethics of humanitarian intervention in particular, are usually considered from the standpoint of 
universality - the violations of universal human rights characteristic of humanitarian emergencies are understandably drawn on in most accounts as a justification for intervention. This approach has its problems, however. One such problem, constituting the point of departure for a Derridean analysis, is the violence done to singularity whenever universals are enforced, even the most noble among them. Suzanne Metselaar gives the example of the ‘inhospitality’ of universal human-rights-based Dutch asylum policy to women in this regard. Failing to take gender into account, the Dutch government blinds itself to how women can be identified as political dissidents in their country of origin without having taken part in conventional dissident activities - for example by taking care of politically persecuted people through providing food and shelter, acts which are often labelled as resistance in the country of origin. ${ }^{2}$ Derrida's challenge to cosmopolitans, whether at home (in asylum policy) or abroad (in humanitarian intervention), is to conceive of how it might be possible to respond to the call of the Other without turning the Other into the Same - a homogenised humanity of interchangeable men and women with all the violence which this threatens to unique and irreplaceable lives. ${ }^{3}$

Derrida's account of hospitality may be of some help in facing up to this not inconsiderable challenge. Most students of international relations will know hospitality only via Immanuel Kant's reflections on a cosmopolitan right of hospitality as outlined in Perpetual Peace. Kantian hospitality, though universal in scope, is limited in substance to a right of visitation, and the visitor, considered as a general category, may indeed be turned away if so doing will not cause his death. ${ }^{4}$ The dominance of this parsimonious Kantian thought of hospitality leads Derrida to reflect that 'we do not yet know what hospitality beyond this European, universally European, right is' ${ }^{5}$ Seeking to open up the space of hospitality beyond its Kantian limitations, Derrida's thought of hospitality is hyperbolic by contrast. Indeed, the 
importance of hospitality for Derrida, and why for him hospitality is ethics, is that it is precisely an unconditional welcome of the stranger in all his strangeness or the foreigner in all his foreignness. As we shall see, Derrida's hospitality-ethics thus involves a significant departure from Kantian hospitality and from Kantian ethics generally: a shift from conditional to unconditional hospitality which is also a shift from the universal accounts of otherness characteristic of Kantian ethics towards a universal openness to the other as Other. In this unconditional welcome of the foreigner, a foreigner who thereby avoids the violence of assimilation, remaining absolutely foreign or Other, Derridean hospitality-ethics offers, at least potentially, a much needed alternative mode of thinking through cosmopolitan duties from the standpoint of singularity. And as Derrida puts it, 'Justice always addresses itself to singularity, to the singularity of the other, despite or even because it pretends to universality' ${ }^{6}$

Openness to the coming of the Other, or unconditional hospitality, leads however to a paradox (Derrida calls it an aporia, or no-road) in the practice of hospitality-ethics, the implications of which will be central to this article. It is impossible, or rather self-defeating an unconditional welcome annuls the home of hospitality. But, refusing us a good conscience about this necessary limitation, conditional hospitality is haunted by the spectre of the abused or absent guest; it is always too conditional, always inadequate to the spirit of hospitality which, beyond all limitation, domestication or assimilation, beyond all violence to the Other, claims no sovereignty over the home at all, opening the door not only to the invited guest but to the unexpected visitation of the unknown, nameless stranger. Hospitality cannot be practiced without limiting it, but this delimited practice creates the demand for its unlimited form. The binary, conditional-unconditional hospitality, then, is indissoluble or inescapable; there can be no final synthesis or dialectical resolution of the two laws of hospitality. Each 
pole is as inseparable from as it is irreducible to the other. Hospitality 'defies dialectics' precisely because there is a 'double law' in play - two imperatives pull each act of hospitality in different directions at the same time. ${ }^{7}$

The defiance of dialectics characteristic of the ethics of hospitality implies a very different understanding of ethics to the Kantian approach dominant in the international relations literature on humanitarian intervention. Given that more than one imperative is operational in the ethics of hospitality, there can be no comprehensive or final answer to the question 'what should I do?'. Undecidability now defines the nature of our duties to others. Since hospitalityethics involves perpetual contestation between two determined duties (conditional and unconditional hospitality) 'if I want to respond in the name of justice, I have to invent singularly', in the absence of any universalisable principle, which is to say norm or law. ${ }^{8}$ With regard to each and every foreigner that comes I must take a position between the poles of hospitality, knowing that this is not, and could never be, a generalisable decision. Undecidability in hospitality-ethics thus imposes a weight of decision that is indisputably troubling, perhaps even fostering a fatalism that can clear the field for unethical, that is inhospitable, practices. But could we be ethical at all without taking on the burden of decision in a context defined by undecidability? In Derrida’s thinking, because undecidability opens up space for, indeed requires, fresh decision, it is a prerequisite of responsibility. Derrida draws on the example of a judge's decision to drive the point home: without taking responsibility for a unique decision based on the relative merits of each case, would we say that justice had been done? For humanitarian interveners animated by the claims of justice, the implications of Derrida's assertion that just decisions must defy dialectics, that they should embrace undecidability, need to be explored properly. 
Although there is now a poststructuralist literature in international relations which has suggested that undecidability is central to ethics, international or otherwise, it has concentrated on a critique of liberal cosmopolitan ethics. The implications of undecidability for cosmopolitan ethical practice as such have not been thought through sufficiently. For example, in reading the conclusion to one insightful article on the uses of Derridean thought for international relations scholarship, readers are nonetheless left with a sense of wanting to know more about how exactly undecidability 'does not lead to passivity...but to action and ethico-political responsibility in the here and now'. ${ }^{9}$ While the point is well taken (and will indeed be reiterated) that undecidability precisely cannot be programmed in advance without closing down the fresh judgement that it inescapably calls forth, there is a pressing need to think through some of its implications for cosmopolitan political practice understood as a general field rather than in application to particular cases, where the risk of contradicting the principle of undecidability would indeed be inescapable.

This article seeks to begin to address this lacuna by applying the discussion of ethical undecidability to the field of humanitarian intervention. To be sure, on one level few would disagree that undecidability is the context within which humanitarian decision-makers must operate. Not intervening may leave non-interveners with blood on their hands, as the spectre of Rwanda testifies; failure to calculate adequately the risks of intervention can spill a lot too, as the haunted looks on the faces of those who argued for the Iraq invasion on humanitarian grounds demonstrate in their turn. However, that this paradox goes all the way down, that undecidability in humanitarian intervention is ethical rather than merely a function of the imperfect information available to decision-makers, would generally be resisted in traditional international relations literatures on, for example, the problem of the lesser evil or on the irreducibility of dilemmas in foreign policy choices. ${ }^{10} \mathrm{I}$ argue, to the contrary, that 
undecidability in international intervention does go all the way down, that the welcome of hospitality and the force of intervention cannot be divorced from one another even as they remain permanently unhappy bedfellows. It is in the moment of undecidability that this opens up between hospitality - which involves responsibility for the Other who comes - and intervention - where it is a matter of responsibly for those others who, particularly for reasons of 'supreme humanitarian emergency', ${ }^{11}$ cannot come - that I argue the ethics of humanitarian intervention must be located.

Before continuing further, one controversial aspect of the argument that follows needs to be defended. The ‘application' of the ethics of hospitality to humanitarian intervention seems to call for a consideration of specific cases, as some of the reviewers of this piece throughout its various stages have argued. Yet I have resisted this call because, for reasons I hope will become clear, the ethics of hospitality does not, cannot, programme an answer to the question of whether to intervene in specific cases. The choices made by humanitarian decision makers in particular cases, precisely because they take place in a field that I argue is defined by ethical undecidability, cannot be judged from some ethically decidable outside without undecidability collapsing back into decidability. We would, in short, be back with that which was rejected at the outset - a universalising, programmable ethics in which questions such as 'to intervene or not to intervene?' could be decided in advance of particular cases. It is the rejection of this position that lies at the heart of this argument. What can be established, however, and what this article seeks to do above all, is to chart the conditions required for an ethics of hospitality to operate at all in world politics. These conditions form a field, they bound, humanitarian intervention as a practice between two limits which, if reached, could destroy the ethics of hospitality itself - on the one hand an ethical prohibition on intervention which allows violence to decide who can, and more importantly cannot, arrive seeking 
hospitality, and, on the other hand, a domesticating will to intervene which would erase both the category of the foregner and the threshold on which the ethics of hospitality are premised. ${ }^{12}$ Such an argument necessarily relates the ethics of hospitality to humanitarian intervention as a practice, not the practice of humanitarian intervention in specific cases.

\section{The ‘double law' of hospitality}

Insofar as it has to do with the ethos, that is, the residence, one's home, the familiar place of dwelling, inasmuch as it is a manner of being there, the manner in which we relate to ourselves and to others, to others as our own or as foreigners, ethics is hospitality. $^{13}$

Derrida’s 1996 address to the International Parliament of Writers (IPW), published as the essay On Cosmopolitanism, is an accessible way into his thought of hospitality. Derrida was invited to respond in this address to the IPW's Network of Cities of Asylum which, following the Salman Rushdie affair, was established to provide refuge for persecuted writers. The European Charter of Cities of Asylum, launched in Strasbourg, proposed that this city 'offer Salman Rushdie the freedom of the city and declare itself a "City of Asylum” for persecuted intellectuals’ and Strasbourg City Council subsequently adopted a 'Motion regarding Salman Rushdie and his Commitment'. Cities in Europe, North America and Africa then joined the Network (becoming the International Network of Cities of Asylum or INCA). ${ }^{14}$

No doubt the IPW would have expected Derrida to celebrate their cosmopolitan hospitality, and indeed he did, up to a point. Nevertheless, reading between the lines of his address Derrida called for a more expansive vision of the City of Refuge - for an extension of his host's hospitality to include 'the foreigner in general, the immigrant, the exiled, the deported, 
the stateless or the displaced person'. To cite only 'the best known would risk sending the anonymous others back into the darkness from which they find it hard to escape, a darkness which is truly the worst and the condition for all others'. ${ }^{15}$ Making this veiled challenge more explicit, Derrida then recalled Hannah Arendt's 'remark about anonymity and fame' in which Arendt contrasted the respective fates of dogs with names and unidentified strays. This remark, Derrida cautioned, with the famous names in his audience undoubtedly in mind, should be taken especially seriously by an International Parliament of Writers. ${ }^{16}$ What Derrida intended here was to identify cities of refuge, and asylum in general, with the foreigner in all her foreignness, with the nameless stranger, something which the IPW, as with all hosts, fell short of in its offer of a limited, in this case literary, hospitality.

Better by far than a hospitality shown to a well known and invited guest would be an open welcome of the stranger. Asking the foreigner 'what is your name?' should be about acknowledging and welcoming him; we should keep this question 'from becoming a “condition”, a police inquisition, a blacklist or a simple border control’ ${ }^{17}$ This hospitality is always open to whoever comes, to the uninvited, unexpected, unidentifiable, absolutely foreign visitor. The unconditional law of hospitality, because it imposes no limits whatsoever to the coming of the other, is more universal than any cosmopolitan law - it simply 'exceeds juridical, political, or economic calculation'. ${ }^{18}$ But if every stranger who knocked on the door were welcomed unconditionally then the day would come, perhaps soon, certainly sooner or later, when we would no longer have a home to welcome anybody into. Derrida does not dispute this, arguing that this is indeed what pure hospitality is: forsaking our home by opening it up 'to the absolute, unknown, anonymous other'; not merely giving a welcome to the stranger but giving place to them. ${ }^{19}$ Yet neither does Derrida deny that this is practically impossible, that the unconditional law of hospitality requires a threshold or that which is 
'proper' to a home, including that it be the property of some rather than all. Derrida does not doubt that although hospitality calls forth a welcome 'without reserve and without calculation', that we must yet hold back against the unlimited arrival of the Other in order to 'render the welcome effective, determined, concrete, to put it into practice'. And from such necessary conditions for hospitality as such, 'the rights and the duties, the borders, the passports and...the immigration laws' come back in to view. ${ }^{20}$

While hosts and hosting may be necessary to hospitality, they are also, however, what makes it so haunted. Because my 'at home’ supposes a reception of the Other in terms of appropriation, control, and mastery, in short 'according to different modalities of violence, hospitality has a history in much the same way that criminals do. Given that all hospitality is built upon the laws or customs of the host, given that it is 'the familial despot, the father, the spouse, and the boss, the master of the house who lays down the laws of hospitality', this history has been violent indeed. ${ }^{21}$ The historical laws of hospitality condition the welcome of hospitality, reducing the foreigner to the host's own other, the other who enables the host to establish his domesticity as proper. ${ }^{22}$ Hospitality, then, is caught up in the perpetual attempt to account for difference within the host's own language, turning difference into identity, the Other into the Same. Thus it is that Derrida challenges hosts, necessary though their application of the law of unconditional hospitality in particular laws offering limited hospitality is, never to forget that the foreigner 'has to ask for hospitality in a language which by definition is not his own'. ${ }^{23}$ While this is inevitable, could not be otherwise, Derrida refuses to give hosts a good conscience about it. Suspending the violence of hospitality may be 'nearly impossible, an interminable task at any rate', but this is precisely 'Another reason to work urgently to transform things. 24 
The 'double law' of hospitality, given the very instability that it generates, becomes a 'site of strategy and decision’. Far from paralysing action, it spurs action on. ${ }^{25}$ Responsibility for the stranger becomes possible precisely because of this 'historical space which takes place between The Law of unconditional hospitality ... and the conditional laws of a right to hospitality, ${ }^{26}$ If The Law of unconditional hospitality could be codified then there would be nothing left to decide and therefore no responsibility. Ethics, understood as synonymous with knowledge, would determine action and apparently responsible decisions would in fact become merely 'technical applications' of some 'preestablished order' ${ }^{27}$ Returning to the example mentioned earlier: a judge's decision indicates this strong connection between the decision, responsibility and justice. If we are to call a judge's decision just, then it must refer to a decision, to a free, decisive and 'reinstituting act of interpretation, as if ultimately nothing existed of the law, as if the judge himself invented the law in every case. No exercise of the law can be just unless there is a "fresh judgement",. ${ }^{28}$ What this example refers us back to is the core challenge posed by Derrida in 'Force of Law': 'how would this infinite and unconditional hospitality... operate in a practical politics? ${ }^{, 29}$ The answer, clearly, is that 'operationalising' the ethics of hospitality must necessarily be particular to each case, that there is always a decision to be made. But a decision must be made, otherwise nothing is offered and no responsibility is taken. ${ }^{30}$ Undecidability becomes a condition of ethical action rather than an obstacle to it.

In sum, ethics as responsibility for the Other is hospitality, hospitality being the name of that which opens itself up to the face of the Other, what welcomes it: 'The face always lends itself to a welcome and the welcome welcomes only a face'. ${ }^{31}$ However, hospitality also produces undecidability since the face which hospitality welcomes exceeds all thematisation. 'Hospitality and not thematization' as Emmanuel Levinas, and following him Derrida, put it, 
counterpoising hospitality to all totalisation. ${ }^{32}$ And herein lies the double-bind of hospitality: we cannot practice hospitality without violating the singularity of the Other, and yet hospitality must be practiced because, clearly, inhospitality offers nothing. Undecidability then involves deciding singularly each time how to practice a hospitality that must not, but cannot help but, thematise the Other - reducing her to what is already known, assimilating her to the Host or domesticating her in the Home.

\section{Identity and difference in humanitarian intervention}

Undecidability is very far from how the thorny ethics of humanitarian intervention have been described to date. Most answers to the question: 'when is humanitarian intervention justified?' recognise that this question comes up against the deeper issue of identity and difference in international politics, though the attempt is still made to finally reconcile these two poles with regard to intervention. Alex Bellamy, for example, has sought to advance ‘pragmatic solidarism’ as a way beyond the cosmopolitan/communitarian (read: identity /difference) impasse which he rightly identifies as underpinning the positions taken in the debate on humanitarian intervention, whether consciously or not. Pragmatic solidarism is defined as being based on a Rortian sentimentality rather than common humanity:

'Humanitarian intervention ought to be seen not in terms of the upholding of universal moral principles, but rather as theory-informed practice based upon the extension of values created within particular communities'.33 Bellamy’s antifoundationalist liberal interventionism, though articulated in the name of a particular (liberal) political community rather than universal values or common humanity, nevertheless seeks to legitimate humanitarian intervention through Rortian 'sentimental education', an approach which wants to include others, by persuasion rather than force, into our 'we group'. ${ }^{34}$ The problem here is that, since the starting point is the particular (liberal community) rather than the universal (common 
humanity), it is accepted that achieving global consensus on intervention through persuasion is 'not only unlikely but also unachievable'. ${ }^{35}$ In which case, and given that Bellamy is explicit that we should undoubtedly extend 'our' liberal values in cases of humanitarian emergency, what exactly is a 'pragmatic solidarist' interventionism left with apart from force? This is implicitly admitted when Bellamy states that, given the unlikelihood of global consensus on intervention, liberal interveners should comfort themselves with the thought that 'legitimacy is not a question of either having it or not having it, but a question of degrees'. ${ }^{36}$ In his concluding comments, Bellamy states that 'The legitimacy of a particular act of intervention may be assessed only in terms of the arguments put forward by the interveners (using the values and discourses of the interveners as a benchmark)... ${ }^{37}$ But if extending 'our' moral community (the 'we-group') is the issue at stake in humanitarian intervention, if we really can ultimately justify intervention 'by reference to “our” values’ alone, then we are back, full circle, with identity rather than difference. ${ }^{38}$ What started out as a promise of a 'beyond' to identity and difference (or cosmopolitanism/communitarianism in Bellamy’s terms) in humanitarian intervention, ends up dialectically resolved in the direction of (a particular, liberal form of) universality. Only from such a dialectical perspective, can we be given a good conscience about the violence to otherness characteristic of intervention, imagining ourselves, at least in the first instance, to be educating the sentiments or engaging in persuasion.

If attempts to transcend identity/difference in thinking humanitarian intervention lead us back to identity, and therefore to a sanitised picture of the force of intervention, then why not simply come clean about this and argue for a universality that is sufficiently attuned to difference, for a liberal interventionist practice that is sensitive to the violence done to particularity and which therefore sometimes says ‘no’ to intervention? Indeed, Richard 
Devetak has pointed out that leading universalist theorists such as Jurgen Habermas are in fact very cautious and qualified in their support for humanitarian interventions. Devetak quotes Habermas's remark that, because global civil society is underdeveloped, 'a special sort of sensitivity' is required when considering humanitarian interventions. ${ }^{39}$ But the point here is surely that Habermas's concession to non-intervention is heavily qualified by the 'for now' quality of his argument - by implication, once global civil society is sufficiently developed then interventions can proceed apace since sufficient universalism will now be present in world politics; universality is 'known but not yet' ${ }^{40}$ There remains significant doubt, then, about whether even the most sophisticated defence of liberal interventionism takes us beyond dialectics, beyond (imperial?) visions of an ultimate 'resolution' of global identity and difference in the name of the former. ${ }^{41}$

Rejecting dialectical approaches to humanitarian intervention does not imply the relativistic, and thereby self-defeating, rejection of universals, though. Indeed, it is not clear that any of the critics of international intervention are anti-universalist. The critics of liberal interventionism, for example, do not question universality as such, merely what they perceive to be a particular, self-interested - namely Western - version of it. What for Wheeler is a matter of 'Saving Strangers' is then for Chomsky 'The New Military Humanism' 42 Ignatieff's 'Empire Lite' — which asks 'what moral authority rests with a sovereign who murders and ethnically cleanses its own people’—and Tesón’s ‘Ending Tyranny in Iraq’ is for Nardin 'Humanitarian Imperialism’ and for Chandler ‘Empire in Denial’— 'attempts by Western states and international institutions to deny the power which they wield and to avoid accountability for its exercise' ${ }^{43}$ Thus the opponents of intervention see interventions as being in the service of a bogus universalism that reflects hegemonic interests rather than 
universal human needs. This, of course, echoes the concerns of many states in the international system:

\begin{abstract}
Very often, the morality and claimed legitimacy of interventions have in reality been those of dominant nations or groups of nations (One of the views expressed at the New Delhi regional roundtable of the International Commission on Intervention and State Sovereignty, 2001). ${ }^{44}$
\end{abstract}

In practice, legalization of humanitarian intervention is counterproductive...for it can facilitate interventionists exploiting the legality for their own purposes... It is clear that certain Western powers have played with noble principles to serve their own hegemonic interests (The view from Beijing of the ICISS). ${ }^{45}$

In order to pursue the independence, neutrality and the impartiality of humanitarian action, such action must be kept distinct from, and independent of political or military action... We reject the so-called "right” of humanitarian intervention (Final document of the XIII Ministerial Conference of the Non-Aligned Movement of the UN, 2000). ${ }^{46}$

There is a significant problem with these critiques also, however. While they implicitly depend upon appeals to a less partisan universalism in word politics, they are largely silent about what this might look like. Is it indeed possible to articulate a new universalism as the possible basis for humanitarian intervention while at the same time avoiding dialectically reducing global difference to identity in a way that threatens to make humanitarian intervention a tool of a neo-imperialism? For a notable attempt at describing such a universalism, a universalism that does not merely accommodate singularity - whether 
through Rortian persuasion or Habermasian inclusion, where this is always to privilege a specific form of universality - but which starts with it, we now return to Derrida.

\section{Another cosmopolitanism}

Reading Derrida as a universalist or cosmopolitan might come as a surprise to some and, certainly, his thought is not captured by liberal cosmopolitanism, nor by universalism as it is usually understood. Since the Other is unique and irreplaceable, irreducible to any theme, the cosmopolitanism Derrida articulates is not expressible in right (droit) or law: 'I want to insist right away on reserving the possibility of a justice, indeed of a law that not only exceeds or contradicts "law" (droit) but also, perhaps, has no relation to law' ${ }^{47}$ Here, the liberal rights of 'man' are overcome by the 'practically infinite' right of the Other. The abstract, formal equality of liberalism, including liberal cosmopolitanism, is reworked as the 'equitable honouring' of the Other whose difference cannot be conceptualised; between myself and this Other there is 'absolute dissymmetry'. ${ }^{48}$ Justice, on this account, is not capable of being thematised, it is 'unpresentable'. ${ }^{49}$ Justice is irreducible to a given law or right because it is owed to the Other who is always singular. ${ }^{50}$

The influence of Emmanuel Levinas on Derrida here must be identified. For Levinas, human solidarity does not arise from human identity, whether considered biologically, linguistically, or in any other way, but instead in difference - in collective responsibility of each for everyone else. This is a responsibility rooted in the 'irreducible singularity', the infinity, of each and every human being. ${ }^{51}$ Rather than being considered as 'an individual of a genus', 'man must also be thought from the responsibility that [consists in] self putting himself despite himself in the place of everyone, substituted for everyone because of his very noninterchangeability’. ${ }^{52}$ Rather than the horizontal relation of solidarity, for Levinas 
responsibility should be understood in the vertical dimension of my being 'hostage, hostage of all the others who, precisely others, do not belong to the same genre as me'. ${ }^{53}$ Nothing less than a 'bottomless difference' gapes between 'the I who is what it is, singular and identifiable, only through the impossibility of being replaced' and the Other for whom I am uniquely responsible ('the uniqueness of the Ego is the fact that no one can answer in my stead'). ${ }^{54}$ The abstraction of law and right speaks to the general rather than the particular; it cannot capture human alterity, only a totalising vision of a humanity made up of 'interchangeable men'. Left to itself, law is thereby a tyranny, deforming both myself and the Other by judging us according to universal rules which obliterate our differences, effacing the unicity of the face in a generality. This is tantamount to being tried 'in absentia', 'where the face is not present, where there is no one to say 'Here I am”, 55

Taking human singularity as the starting point therefore leads to particular universals, such as cosmopolitan right, being called into question not for claiming universality as such, but rather for failing to be universal enough to do justice to particulars, to particular Others. In Levinas’s schema, this means differentiating between a necessarily transcendental humanism and a humanism characteristic of the zones of power, law and order, which constitutes yet another dangerous totalisation. ${ }^{56}$ Following Levinas, Derrida too calls for a humanism, and by extension for a humanitarianism, which must ceaselessly be challenged and rethought; for a negotiated humanism, a humanism ‘in question’, that avoids the Kantian temptation to see cosmopolitan duties as defined by an already given ethics. Here, openness concerning the ‘rules' of cosmopolitanism in cases such as humanitarian intervention means 'the necessity of a leap at the moment of ethical, political, or juridical decision'. Without this leap, a decision taken in full recognition of undecidability, ethical knowledge could simply be unfolded into a programme. ${ }^{57}$ Derrida says of this latter course of action - and applied to the horrible 
complexities and Hobson's choices of humanitarian intervention his words seem especially apposite - 'Nothing could make us more irresponsible'. ${ }^{58}$

Derrida’s point about undecidability in cosmopolitanism or humanitarianism is not simply that it is the condition of responsibility in the sense of continually requiring fresh decision. Undecidability is also a reference to the impossibility of making a final decision between the universality of law and rights and the singularity of the Other. For Derrida, it is in fact nothing other than 'the same duty [which] dictates respecting differences, idioms, minorities, singularities, but also the universality of formal law, the desire for translation, agreement and univocity, the law of the majority, opposition to racism, nationalism, and xenophobia'. ${ }^{59}$ Or, as Levinas makes the point, 'In the measure that the face of the Other relates us with the third party, the metaphysical relation of the I with the Other moves into the form of the we, aspires to State, institutions, laws which are the source of universality'. ${ }^{60}$ In short, the ethics of hospitality, despite 'starting' with the welcome made to a singular stranger, leads inexorably to the 'third party', that is to humanity as such and thus also to cosmopolitan duties, as the following reading of Levinas by Derrida makes clear:

Levinas insists on the fact that the third one does not appear after the other two as someone else...but is already involved in the face to face relation as a call to justice. At this point we encounter a terrible situation: in order to be just, by taking into account the third one, I have to betray in some way my pure asymmetrical - but dual - relation with the other. This is followed by a complaint in Levinas, a complaint which sounds very much like Job’s complaint: 'What should I have to do with justice, because justice is unjust?'... Nevertheless we cannot, we should not, avoid justice. ${ }^{61}$ 
This leads us back to undecidability. That the call of the Other contains the call of the third party (whom the Other is nonetheless irreducible to) is echoed in the way in which ethics (responsibility for the Other) calls for politics and law (the sphere of the third party) while remaining irreducible to it. ${ }^{62}$ Deducing politics from ethics , then, remains an indeterminate activity, precisely something to be determined. ${ }^{63}$ Undecidability is here a call to responsible action rather than an excuse for inaction.

\section{Hospitality and humanitarian intervention}

Peace, peace to the neighbour and the one far-off. ${ }^{64}$

Even on its own terms, ethics as hospitality does not imply that the practice of hospitality exhausts our ethical responsibilities. If hospitality comes from the face of the Other and the way in which this face demands a welcome, then we must not forget that the Other also comes attached to the third - the call of justice which is necessarily wider than the face-toface relationship with the Other. To welcome only the singular Other is at once to pass by all the others; this 'thirdness' forces us to turn towards others than the Other. In particular, the third interrupting the face to face welcome of the Other challenges our prioritisation of proximity in a neighbour. ${ }^{65}$ This is why Levinas quotes Isaiah 57 above, since through it we understand that though the 'third is other than a neighbour', he is also, despite being far off, 'another neighbour' ${ }^{66}$ 'What' then, writes Levinas, 'am I to do?' 'Who passes before the other in my responsibility?' Thus 'the first question in the interhuman' is nothing other than 'the question of justice'. ${ }^{67}$ The third reintroduces us, forcibly, to the question of justice that the ethics of the Other should exceed; it compels us to be sovereign, that is to consider, by way of 'the comparison of incomparables' (a weighing up of unique lives from the perspective of equity, completely foreign to the ethics of hospitality as this is) what justice 
requires and to enforce it. ${ }^{68}$ And although neither Derrida nor Levinas say so, surely this push from singular ethical responsibility to universal justice requires of us, in certain contexts, to move from hospitality to humanitarian intervention? For what else is the principle at stake in humanitarian intervention than the inescapable move from concern with the Other in hospitality to the third in justice? If it is the face of the 'near' neighbour that compels the welcome of hospitality, it is the face of the suffering 'far' neighbour, the one who cannot make it far enough to arrive at our door, that is the call to justice and thus, in ways always to be decided, sometimes to intervention.

Hospitality and humanitarian intervention, then, are not essentially separate ethical practices. At the other pole to the ethics of unlimited hospitality is not limited hospitality alone but rather a whole series of politico-juridical practices (including, at the extreme, humanitarian intervention) whereby we are compelled to transform our responsibility to the Other into responsibility for all. Limited hospitality, even with its exclusionary and domesticating practices, is necessary in order that justice be done. However, this imperative leads us inexorably from hospitality to intervention since hospitality is precisely an unenforceable justice with regard to many of those caught up in humanitarian emergencies who are not be able to travel to the home (the city or the state) that we might open up to them. Cosmopolitanism as hospitality can never finally separate itself out from intervention, then. ${ }^{69}$ However, while a complete dichotomisation of hospitality and intervention is neither possible nor desirable, they are not the same thing. It matters whether we open our door to the other or go forth forcibly to protect her in her own home. The poles hospitality/intervention are not only indissociable from, but also irreducible to, each other - there is undecidability here. First, hospitality involves a movement inwards, towards the home. Intervention heads in the 
opposite direction, away from the home, outwards. Second, with hospitality it is the other who comes while with intervention it is the host that goes forth. These differences are significant indeed: while each act of hospitality always falls short of pure hospitality, it cannot threaten the global play of hospitality itself. Intervention, on the other hand, to the extent that it threatens global domestication, can. If the perversion of the law of unconditional hospitality involves the domestication of the foreigner in our own home, then how much more perverting of hospitality-ethics is a cosmopolitanism defined as the domestication of the global space itself through interventions? And this ‘cosmopolitanism as domestication' is not a straw man. Mary Kaldor calls for nothing less than 'the domestication of the international' in her Global Civil Society: an answer to war ${ }^{70}$ Less explicitly, but moving in the same direction, see also Andrew Linklater's influential argument in The Transformation of Political Community that 'The task of cosmopolitan citizenship is to project the achievements of national citizenship out into the sphere of international relations' and that those outside cosmopolitanised parts of the globe should be brought in so that 'they can defend their legitimate interests by participating in effective universal communicative frameworks' ${ }^{71}$ What ties Linklater's critical project to those of liberals such as Kaldor is a 'domestication of the international' in the sense that 'the international is understood in terms of the domestic'. As Edkins and Zehfuss argue, any account which 'seeks to provide order (which is found in the domestic) in the international ... is implicitly based on the very possibility of domesticating the international' ${ }^{72}$

Ultimately, with global domestication there simply can be no worldwide field of hospitality because no outside is left. We have not one but two degrees of separation from unconditional hospitality here: conditional hospitality, at one remove, is a flawed but necessary 'inviting in' to a limited sphere defined by sovereignty and therefore by domestication of the other. 
Liberal interventionism, at two removes, appears as a domestication that claims everywhere as home. Consider, for example, the Blair 'doctrine of the international community'. In his celebrated speech in 1999 to the Economic Club, Chicago, then British Prime Minister Tony Blair qualified his desire to intervene wherever there are 'undemocratic' and 'barbarous' regimes with the argument that 'then we would do little else than intervene in the affairs of other countries'. But this was immediately revealed to be a prudential, rather than a principled, rejection of such widespread interventions when Blair went on to add that 'We would not be able to cope'. Also illustrating that whether to intervene was not at issue for him, Blair stated elsewhere in this speech that the 'most pressing' problem in foreign policy is 'to identify the circumstances in which we should get actively involved in other people's conflicts'. ${ }^{73}$

This form of liberal interventionism seems destroying of unconditional hospitality since hospitality, as we have seen, clearly requires two things: that I have a 'home' over which I am more or less sovereign in order to have a place to invite the other into, but also that there is a place outside the home from which the other arrives. If the foreigner 'was already speaking our language, with all that that implies, if we shared everything that is shared with a language, would the foreigner still be a foreigner and could we speak of asylum or hospitality in regard to him?'. ${ }^{74}$ Without the threshold, there would be no possibility of hospitality. ${ }^{75}$ If ethics is hospitality then it appears incompatible with the domestication of the global space sought through extensive international interventions. There remains a significant difference between a liberal cosmopolitanism which consists in bringing those outside the home of cosmopolitan right in by expanding the borders of that home until they, and the sovereignty they represent, span the globe, and a cosmopolitanism as hospitality which focuses on the welcome offered to those who come. The latter, despite its undoubted violence, stays true to 
the notion that ethics is hospitality and keeps alive the (im)possibility of renouncing sovereignty. ${ }^{76}$

And yet, where singularities are threatened with extreme violence, even to the point of extinction, then hospitality - with the protection that it affords only to those who can make it to safety within the host's walls - might well be ethically insufficient, and not simply unjust. To remain at home when mass murder is taking place abroad is to allow the worst violence to settle the question of who comes, since those who arrive seeking hospitality will of course only be those who escaped with their lives. Being open to the coming of the Other, then, may sometimes involve going forth to protect him in his own home, an intervention without which there may be no further possibility of a coming of that Other at all. Non-intervention can be party, through inaction, to a violent eradication of difference far worse than the violence it itself visits through assimilation of the singularity of those who come. In short, intervention may be part of our ethically limitless responsibility to singular Others, and not only to generalised others ('the third') in justice.

\section{Conclusion}

Undecidability in the ethics of hospitality is not only undecidability between conditional and unconditional hospitality, which relates only to those who arrive as now neighbourly strangers, and not to strangers who remain 'far off'. In relation to distant strangers the undecidability is that between hospitality and intervention. Crucially, though, ethical undecidability between hospitality and intervention is a 'bounded undecidability' in which each pole both calls to and challenges the other; it is manifestly not a blind leap in the dark. The fact that two very different moral imperatives weigh on us with equal force is very far from relativism. That this is the case is demonstrated by the fact that the 'bounded 
undecidability’ of ethics as hospitality has clear implications for humanitarian intervention as a practice (if not for the practice of humanitarian intervention in specific cases): at either extreme, neither liberal interventionism nor non-interventionism seems compatible with the ethics of hospitality. Liberal interventionism threatens such a thorough domestication of the world order that there may conceivably no longer be a foreigner to come. In this case, though there may be justice in the form of universal law or right, there is no longer any possibility of conceiving of pure hospitality, of a non-sovereign relation to the Other. Non-interventionism, meanwhile, to the extent that it is based on a critique of the use of force in intervention, mistakenly assumes that there is a 'clean hands' option, thereby missing the violence done to otherness when offering what will be a necessarily limited, sovereign, hospitality. It forgets also that even 'pure hospitality' would reintroduce the violence of injustice in the absolute prioritisation of the Other who comes over all the others (not to mention the violence that unconditional hospitality threatens to myself as host, to 'myself as Other'). Most importantly, however, non-interventionism is blind to the way in which hospitality alone in a violent world also cannot ultimately guarantee that there will be specific others left to come.

If liberal interventionism misses the ethical harm of a world without the threshold boundaries (as limits to the violence of the sovereign home) ${ }^{77}$ then non-interventionism misses the injustice caused by the threshold (as putative limits to ethical responsibility). ${ }^{78}$ Thus the question of whether to intervene or not to intervene is at the same time both a bounded and an open ethical question - 'bounded undecidability', it could be said. Nothing we do for strangers, no more hospitality than intervention, can avoid violence to their irreducible singularity, but both a universalised commitment to intervention and a universalised commitment to non-intervention could conceivably lead to a situation where there is no Other left to come. While the ethics of hospitality set a real limit to intervention since universal 
domestication is incompatible with the foreigner, intervention is a sometimes necessary extension of hospitality’s care for particular foreigners. Judging whether to intervene or not to intervene on the basis of an ethics in which the threshold is both the occasion for and an obstacle to ethical responsibility will come hard for liberal cosmopolitans reared on the certainties (the decidability) of an ethics without borders. But the hard political choices which emanate from the 'bounded undecidability' of ethics as hospitality remain the only way to keep responsibilities to others in tension with openness to the coming of the Other. 


\section{Notes}

${ }^{1}$ For a more general statement identifying cosmopolitanism with the ethics of hospitality, see my 'Cosmopolitanism as Hospitality: Revisiting Identity and Difference in

Cosmopolitanism', Alternatives, 34(2), 2009.

${ }^{2}$ Suzanne Metselaar, 'When Neighbours Become Numbers: Levinas and the Inhospitality of Dutch Asylum Policy’, Parallax, 11(1), 2005, p. 65.

${ }^{3}$ Where the $\mathrm{O}$ in Other is capitalised, Derrida, following Emmanuel Levinas, is referring to the transcendence of the stranger, to his or her irreducibility to any theme. I follow this practice here.

${ }^{4}$ Immanuel Kant, 'Perpetual Peace: a philosophical sketch', in H.S. Reiss (ed.) Kant's

Political Writings (Cambridge: Cambridge University Press, 1970), pp. 105-6.

${ }^{5}$ Jacques Derrida, 'Hostipitality’, Angelaki, 5(3), 2000, pp. 10-11. For an extended discussion on the difference between Kantian and Derridean hospitality, see Gideon Baker, 'The Politics of Hospitality: sovereignty and ethics in political community, in Gideon Baker and Jens Bartelson (eds.) The Future of Political Community (London: Routledge, 2009).

${ }^{6}$ Jacques Derrida, 'Force of Law: The “Mystical Foundation of Authority”', Cardozo Law Review 921, 1990, p. 955.

${ }^{7}$ Derrida, 'Force of Law, p. 967.

${ }^{8}$ Jacques Derrida, 'Hospitality, Justice and Responsibility: A Dialogue with Jacques

Derrida', in R. Kearney and M. Dooley (eds.) Questioning Ethics: Contemporary Debates in Philosophy (London: Routledge 1999), p. 72.

${ }^{9}$ Jenny Edkins and Maja Zehfuss, 'Generalising the International', Review of International Studies, 31, 2005, p. 471.

${ }^{10}$ Thanks to Ken Booth for reminding me that the Derridean problematic of undecidability is by no means a new one in international relations theorising. Derrida himself, of course, also gets it from elsewhere - particularly from Kierkegaard.

${ }^{11}$ Nicholas J. Wheeler, Saving Strangers: Humanitarian Intervention in International Society, (Oxford: Oxford University Press, 2000).

12 Jacques Derrida, Adieu: to Emmanuel Levinas, trans. Pascale-Anne Brault and Michael Nass (Stanford, CA: Stanford University Press, 1999), pp. 46 and 92.

13 Jacques Derrida, On Cosmopolitanism and Forgiveness (London: Routledge, 2001), p. 16. See also: '[Hospitality] is ethicity itself, the whole and the principle of ethics' (Derrida, Adieu, p. 50).

${ }^{14}$ S.E. Kelly, 'Derrida’s Cities of Refuge: Toward a Non-Utopian Utopia’ Contemporary Justice Review, 7(4), 2004, pp. 421-439. INCA was disbanded in 2005, to be replaced by the International Cities of Refuge Network (ICORN) and Cities of Refuge North America. In its founding Charter, ICORN responds to the ongoing persecution of writers by providing ' $\mathrm{a}$ functioning network of cities and regions that will provide shelter for persecuted writers' (Charter available at: http://www.icorn.org/resource/userfiles/TheCharter/Eng- 
TheCharter.pdf (1 May 2007)). Cities of Refuge North America, meanwhile, 'helps writers, persecuted and silenced in their native countries, to find safe haven in North America...' (http://www.citiesof refuge.com (1 May 2007)).

${ }^{15}$ Derrida, On Cosmopolitanism, p. 6.

${ }^{16}$ Derrida, On Cosmopolitanism, p. 15.

${ }^{17}$ Jacques Derrida, in G. Borradori, Philosophy in a Time of Terror: Dialogues with Jurgen Habermas and Jacques Derrida (University of Chicago Press: Chicago, 2003), p.129.

${ }^{18}$ Jacques Derrida, 'The World of the Enlightenment to Come (Exception, Calculation, Sovereignty)', Research in Phenomenology, 33, 2003, p. 40.

${ }^{19}$ Jacques Derrida, Of Hospitality (Stanford CA: Stanford University Press, 2000), p. 25.

${ }^{20}$ Jacques Derrida, 'The Principle of Hospitality', Parallax 11(1), 2005, p. 6. Considering hospitality as a concept rather than a practice we get the same paradoxical result or 'double law'. The foreigner/host relation sets the logical, and not simply the material, limits of hospitality. For hospitality there must first be a foreigner; and, for the foreigner to appear foreign in the first place, there must be hospitality.

${ }^{21}$ Derrida, Of Hospitality, p. 149.

${ }^{22}$ Kelly, 'Derrida’s Cities of Refuge’, p. 429.

${ }^{23}$ Derrida, Of Hospitality, p. 15.

${ }^{24}$ Derrida, 'The Principle of Hospitality', p. 7.

${ }^{25}$ Derrida, 'The Principle of Hospitality', p. 6. See also Derrida, Of Hospitality, pp. 147-8.

${ }^{26}$ Derrida, On Cosmopolitanism, p. 22; see also p. 45.

${ }^{27}$ Jacques Derrida, Aproias (Stanford, CA: Stanford University Press, 1993), pp. 16-17. See also: Jacques Derrida, The Other Heading: Reflections on Today's Europe, trans. PascaleAnne Brault and Michael B. Nass, (Bloomington: Indiana University Press, 1992), pp. 41, 45 and 72; Derrida, On Cosmopolitanism (pp. 53-4); and Derrida, 'Hospitality, Justice and Responsibility', pp. 65-7.

${ }^{28}$ Derrida, 'Force of Law', pp. 961-3.

${ }^{29}$ Derrida, 'Force of Law', p. 91.

${ }^{30}$ Derrida, Adieu, p. 21.

${ }^{31}$ Derrida, Adieu, p. 21.

${ }^{32}$ Derrida, Adieu, p. 22.

${ }^{33}$ Alex Bellamy, 'Pragmatic Solidarism and the Dilemmas of Humanitarian Intervention', Millennium, 31(3), 2002, p. 489.

${ }^{34}$ Bellamy, 'Pragmatic Solidarism', pp. 491-2

35 Bellamy, 'Pragmatic Solidarism’, p. 492.

${ }^{36}$ Bellamy, 'Pragmatic Solidarism’, p. 492.

${ }^{37}$ Bellamy, 'Pragmatic Solidarism', p. 496.

${ }^{38}$ Bellamy, 'Pragmatic Solidarism’, p. 497.

${ }^{39}$ Jurgen Habermas, 'Bestiality and Humanity: A War on the Border between Legality and Morality', Constellations, 6(3), 1999, p. 267; cited in Richard Devetak, 'Between Kant and Pufendorf: Humanitarian Intervention, Statist Anti-Cosmopolitanism and Critical International Theory', Review of International Studies, 33, 2007, p. 174. 
${ }^{40}$ Kimberly Hutchings, 'Happy Anniversary! Time and critique in international relations theory', Review of International Studies, 33, 2007, pp. 71-89. Devetak, following Linklater (Andrew Linklater, 'The Good International Citizen and the Crisis in Kosovo', in Albrecht Schnabel and Ramesh Thakur (eds.), Kosovo and the Challenge of Humanitarian Intervention (Tokyo: UN University Press, 2000), p. 488), in fact avoids this problematic line of defence, suggesting instead that 'deciding whether or not armed intervention may be legitimate for humanitarian purposes must surely be a matter for judgement depending on particular circumstances, not something one can judge in advance' (Devetak, 'Between Kant and Pufendorf', p. 174).

41 'trying to extend the apparent consensus and security of the domestic to the international [is] inevitably an imperial imposition' (Edkins and Zehfuss 'Generalising the International', p. 470).

${ }^{42}$ Wheeler, Saving Strangers; Noam Chomsky, The New Military Humanism: Lessons from Kosovo (Monroe, ME: Common Courage Press, 1999).

${ }^{43}$ Michael Ignatieff, Empire Lite, available at http://empirelite.ca (12 April 2007). Fernando Tesón, 'Ending Tyranny in Iraq’, Ethics and International Affairs, 19(2), 2005, pp. 1-20.

Terry Nardin, 'Humanitarian Imperialism', Ethics and International Affairs, 19(2), 2005, pp. 21-6. David Chandler, Empire in Denial: The Politics of State-Building (London: Pluto Press, 2006), p. 1.

${ }^{44}$ 'Background’ to final report, available at: http://www.iciss.ca/report-en.asp, p. 388. (15 April 2007).

45 The Responsibility to Protect, 'Background', p. 392.

${ }^{46}$ Available at: http://www.nam.gov.za/xiiiminconf/final4.htm. (15 April 2007)

${ }^{47}$ Derrida, 'Force of Law', p. 925.

${ }^{48}$ Derrida, 'Force of Law', p. 959.

${ }^{49}$ Derrida, 'Force of Law', p. 971.

${ }^{50}$ Derrida, 'Force of Law', p. 965.

${ }^{51}$ David J. Gauthier, 'Levinas and the Politics of Hospitality', History of Political Thought, 28(1), 2007, p. 167.

${ }^{52}$ Emmanuel Levinas, Humanism of the Other, trans. N. Poller, (Champaign, IL: University of Illinois Press, 2006), p. 68.

${ }^{53}$ Levinas, Humanism of the Other, p. 68.

${ }^{54}$ Derrida, Adieu, p. 6; Levinas, Humanism of the Other, p. 33.

${ }^{55}$ Emmanuel Levinas, Totality and Infinity: an Essay on Exteriority, trans. A. Lingis (The Hague: Martins Nijhoff, 1981), p. 300; Derrida, Adieu, pp. 97-8.

${ }^{56}$ Levinas, Humanism of the Other, p. 67.

${ }^{57}$ Derrida, Adieu, p.117.

${ }^{58}$ Derrida, Adieu, p. 117.

${ }^{59}$ Derrida, The Other Heading, p. 78.

${ }^{60}$ Levinas, Totality and Infinity, p. 300.

${ }^{61}$ Derrida, ‘Hospitality, Justice and Responsibility', pp. 68-9.

${ }^{62}$ Derrida, Adieu, pp. 29-32. Or, as Levinas makes the same point, 'the substitution of the one for the other does not imply the substitution of the other for the one.' (Emmanuel Levinas, 
Otherwise than Being or Beyond Essence, trans. A. Lingis (The Hague: Martinus Nijhoff, 1981), p. 158.)

${ }^{63}$ Francois Raffoul, 'On Hospitality: Between Ethics and Politics', Research in

Phenomenology, 28(1), 1990, pp. 274-283, p. 280.

${ }^{64}$ Isaiah 57:19, cited in Levinas, Otherwise than Being, p. 157.

${ }^{65}$ Derrida, Adieu, p. 29.

${ }^{66}$ Levinas, Otherwise than Being, p. 157.

${ }^{67}$ Cited in Derrida, Adieu, p. 32.

${ }^{68}$ Derrida, Adieu, p. 30.

${ }^{69}$ For more on how I define 'cosmopolitanism as hospitality', see my article by the same name in Alternatives, 34(2), 2009.

${ }^{70}$ Mary Kaldor, Global Civil Society: an Answer to War? (Cambridge: Polity Press, 2001).

${ }^{71}$ Andrew Linklater, The Transformation of Political Community (Cambridge: Polity Press, 1998), pp. 212 and 206, emphasis added.

${ }^{72}$ Edkins and Zehfuss, 'Generalising the International', pp. 462-463.

${ }^{73}$ Speech available at: http://www.number10.gov.uk/output/Page1297.asp (2 April 2007).

${ }^{74}$ Derrida, Of Hospitality, p. 15.

${ }^{75}$ Derrida, Of Hospitality, p. 65.

${ }^{76}$ For more on the irreducibility of sovereignty to an ethics of hospitality, see my 'The Politics of Hospitality'.

${ }^{77}$ Derrida accords with Levinas that hospitality, the welcome of the Other, requires a 'pluralism in which the plurality is not that of a total community, that of the cohesion of the whole'. Derrida quotes Levinas at this point: 'The unity of plurality is peace, and not the coherence of the elements that constitute plurality... Peace must [therefore] be my peace, in a relation which starts from an $I$ and goes to the other, in desire and goodness, where the I both maintains itself and exists without egoism.' For Levinas, all other peace is but 'the peace of empires' (Derrida, Adieu, pp. 96-7, emphasis added).

${ }^{78}$ From the perspective of the ethics of hospitality, the home exists to make the welcome possible and this 'is its sole destination'. Following Levinas in departing here from the phenomenological tradition, Derrida sees the home as the 'possibility of the welcome' rather than the welcome of possibility (Derrida, Adieu, p. 28). The dwelling is justified only in the welcome of hospitality, having 'nothing natural about it, nothing of a root'. 'Hospitality thus precedes property' and the threshold is defined not as that which shuts out the Other but as that which opens on to her (Derrida, Adieu, pp. 92 and 45). 